\title{
PRION DISEASE RESEMBLING FRONTOTEMPORAL DEMENTIA AND PARKINSONISM LINKED TO CHROMOSOME 17
}

\author{
Ricardo Nitrini', Luís Sidônio Teixeira da Silva², Sérgio Rosemberg ${ }^{3}$, Paulo Caramelli ${ }^{4}$, \\ Paulo Eduardo Mestrinelli Carrilho ${ }^{5}$, Paula lughetti ${ }^{6}$, Maria Rita Passos-Bueno ${ }^{7}$, \\ Mayana Zatz ${ }^{8}$, Stephen Albrecht ${ }^{9}$, Andrea LeBlanc ${ }^{10}$
}

\begin{abstract}
Objective: To compare the clinical features of a familial prion disease with those of frontotemporal dementia and parkinsonism linked to chromosome 17 (FTDP-17). Background: Prion diseases are not usually considered in the differential diagnosis of FTDP-17, since familial Creutzfeldt-Jakob disease (CJD), the most common inherited prion disease, often manifests as a rapidly progressive dementia. Conversely, FTDP-17 usually has an insidious onset in the fifth decade, with abnormal behavior and parkinsonian features. Method: We present the clinical features of 12 patients from a family with CJD associated with a point mutation at codon 183 of the prion protein gene. Results: The mean age at onset was $44.0 \pm 3.7$; the duration of the symptoms until death ranged from two to nine years. Behavioral disturbances were the predominant presenting symptoms. Nine patients were first seen by psychiatrists. Eight patients manifested parkinsonian signs. Conclusion: These clinical features bear a considerable resemblance to those described in FTDP-17.
\end{abstract}

KEY WORDS: prion protein mutation, prion disease, Creutzfeldt-Jakob disease, frontotemporal dementia, parkinsonism.

Doença priônica com características clínicas semelhantes à demência frontotemporal e parkinsonismo associada ao cromossoma 17.

RESUMO - Objetivo: comparar as características clínicas de doença priônica com as da demência frontotemporal e parkinsonismo associada ao cromossoma 17 (FTDP-17). Fundamentos: doenças priônicas não são usualmente incluídas no diagnóstico diferencial da FTDP-17 porque a doença de Creutzfeldt-Jakob (DCJ), a mais comum entre as doenças priônicas hereditárias, frequentemente manifesta-se como demência rapidamente progressiva. Por outro lado, a FTDP-17 apresenta-se insidiosamente na quinta década, com alterações do comportamento e sinais parkinsonianos. Método: apresentamos as características clínicas de 12 membros de uma família com DCJ associada à mutação de ponto no codon 183 do gene da proteína priônica. Resultados: os sintomas iniciaram-se aos $44.0 \pm 3.7$ anos e a duração até o óbito foi de dois a cinco anos. Alterações do comportamento foram os sintomas iniciais mais frequentes. Nove pacientes foram atendidos inicialmente por psiquiatras. Oito pacientes manifestaram sinais parkinsonianos. Conclusão: as características clínicas apresentam considerável semelhança com as descritas na FTDP-17.

PALAVRAS-CHAVE: mutação da proteína priônica, doença priônica, doença de Creutzfeldt-Jakob, demência frontotemporal, parkinsonismo.

Creutzfeldt-Jakob disease (CJD) and GerstmannSträussler-Scheinker disease (GSSD) are the prion diseases in which dementia is an important part of the clinical syndrome. The clinical picture of CJD is characterized by a very rapidly progressive dementia, associated with myoclonus, cerebellar, pyramidal and extrapyramidal signs ${ }^{1}$. In GSSD, the classical presentation is a slowly progressive cerebellar syndrome

\footnotetext{
${ }^{1} \mathrm{MD}$, Associate Professor, Department of Neurology, Faculty of Medicine, University of São Paulo, São Paulo, Brazil; ${ }^{2} \mathrm{MD}$, Assistant Professor, Department of Internal Medicine, State University of Londrina, Londrina, Brazil; ${ }^{3} \mathrm{MD}$, Associate Professor, Department of Pathology, Faculty of Medicine, University of São Paulo, São Paulo, Brazil; ${ }^{4}$ MD, Assistant Professor, Department of Neurology, Faculty of Medicine, University of São Paulo, São Paulo, Brazil; ${ }^{5} \mathrm{MD}$, Department of Neurology, Faculty of Medicine, University of São Paulo, São Paulo, Brazil; ${ }^{6} \mathrm{PhD}$, Assistant Professor, Department of Human Genetics, Faculty of Biology, University of São Paulo, São Paulo, Brazil; ${ }^{7} \mathrm{PhD}$, Associate Professor, Department of Human Genetics, Faculty of Biology, University of São Paulo, São Paulo, Brazil; ${ }^{8}$ PhD, Professor, Department of Human Genetics, Faculty of Biology, University of São Paulo, São Paulo, Brazil; ${ }^{9}$ MD, Department of Pathology, McGill University, Montreal, Quebec, Canada; ${ }^{10} \mathrm{PhD}$, Associate Professor, Department of Neurology and Neurosurgery, McGill University, Montreal, Quebec, Canada.
}

Received 25 October 2000, received in final form 19 December 2000. Accepted 22 December 2000. 
with dementia occurring later, and a mean duration of illness of five years. About 15\% of CJD cases and almost all GSSD cases are inherited as an autosomal dominant disorder ${ }^{1,2}$

Frontotemporal dementia and parkinsonism linked to chromosome 17 (FTDP-17) is an autosomal dominant disorder associated with mutations in the tau protein gene, which is located in chromosome $17^{3}$. The clinical features of FTDP-17 are primarily abnormal behavior (impaired social conduct ranging from disinhibition to apathy; hyperorality; stereotyped behavior; psychotic symptoms) and disturbed executive function combined with relatively preserved memory and visuo-spatial functions. Parkinsonian features are common. The symptoms usually begin insidiously, typically in the fifth decade, and the duration of the disease varies between the extremes of 3 to 30 years.

In the differential diagnosis of FTDP-17, other frontotemporal dementias, parkinsonian syndromes associated with behavior disturbances, and even early-onset Alzheimer's disease, should be included ${ }^{4}$. Conversely, CJD and GSSD are not usually considered, mainly because most of the familial forms of CJD present clinical features similar to the sporadic form, with a rapidly progressive multifocal dementia as the hallmark ${ }^{1}$, while GSSD is characterized by the cerebellar syndrome ${ }^{1,2}$

In a previous study, our group described nine cases of a Brazilian family with the prion disease associated with a point mutation at codon 183 of the prion protein gene causing the substitution of threo- nine by alanine $(\mathrm{T} 183 \mathrm{~A})^{5}$. In the present study, we include three new cases of the same family, and we describe in more detail the clinical features of the disease.

\section{METHOD}

Nineteen individuals of the same family, 6 women and 13 men, in four generations, were reported by their relatives to be affected by the disease (Fig 1). We collected all available information from several sources: 1) medical/ hospital registers, information from relatives, and neuropathological examination (three cases: II-6, III-6 and III25); 2) medical/hospital registers and information from relatives (nine cases: III-3, III-4, III-8, III-19, III-21, III-24, IV13, IV-15 and IV-62); 3) information from relatives (seven cases: I-1, II-1, II-5, III-2, III-5, III-20 and IV-14). For the description of the clinical features, we used only the data from 12 patients with medical/hospital records. Four of these patients (III-19, III-25, IV-15, IV-62) were also examined by the first author.

\section{RESULTS}

Table 1 summarizes the main clinical data.

The mean age at onset of the clinical symptoms was $44.0 \pm 3.7$, the mean age at death, $48.5 \pm 5.0$ years, and the mean duration of the symptoms was $4.2 \pm 2.3$ years, ranging from two to nine years. Behavioral disturbances were the predominant features at the beginning of the symptoms, with apathy and depression being more frequent than disinhibited behavior. Executive dysfunctions also were often reported as the initial manifestation in several patients. As the disease advanced, behavioral

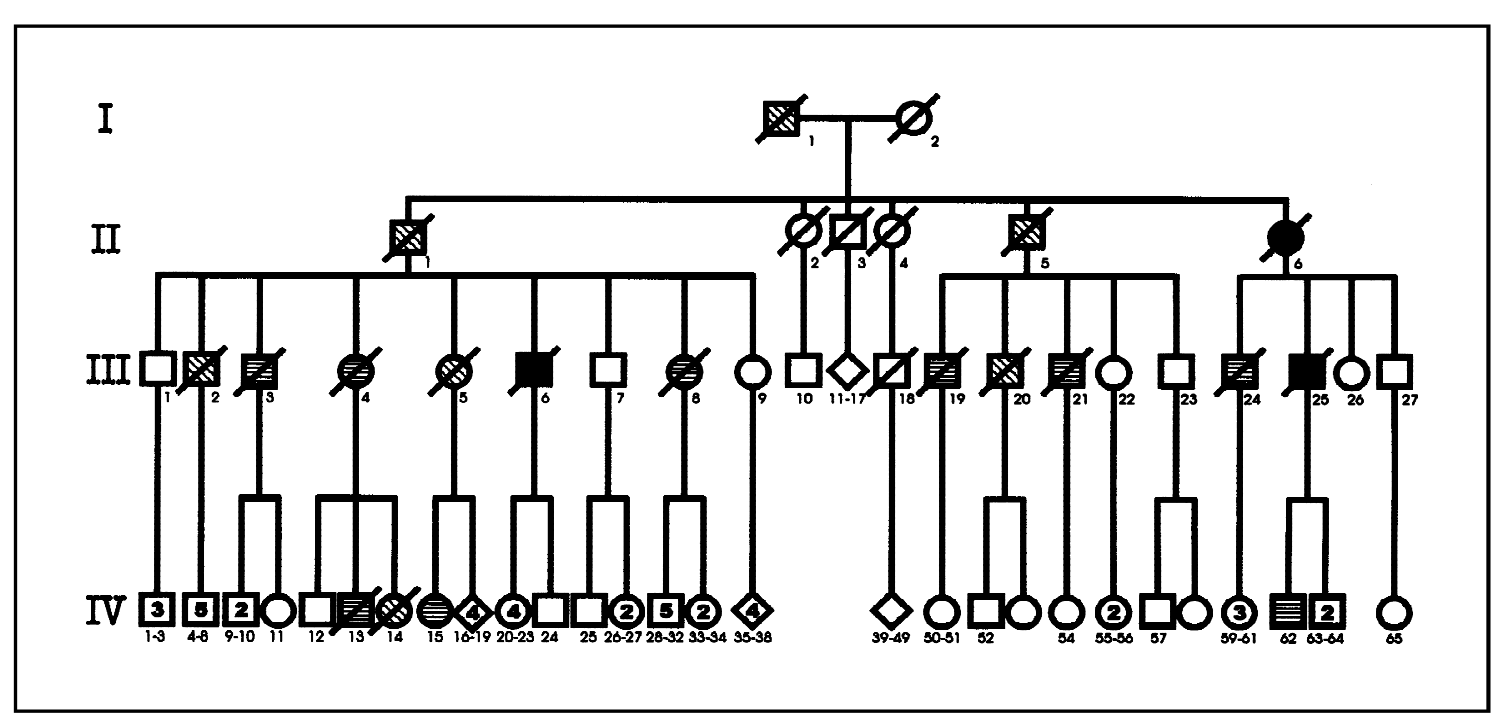

Fig 1. Pedigree of the family with T183A mutation. Solid symbols indicate pathologically confirmed cases, horizontal lines within the symbols indicate that data were obtained from medical/hospital registers and family information, and oblique lines within the symbols indicate that data were obtained exclusively from family information. Symbols with a diagonal line denote deceased individuals. Circles, females; squares, males; diamonds, either gender. 
Table 1. Case summaries of 12 patients with the prion disease associated with T183A mutation.

\begin{tabular}{|c|c|c|c|c|c|c|}
\hline Patient & Gender & $\begin{array}{l}\text { Age at } \\
\text { onset, } \\
\text { (year) }\end{array}$ & $\begin{array}{l}\text { Symptoms } \\
\text { Duration, } \\
\text { (year) }\end{array}$ & Initial symptoms & Subsequent symptoms & Comments \\
\hline II-6 & $\mathrm{F}$ & 46 & 02 & $\begin{array}{l}\text { Irritability; paranoid delusions; } \\
\text { inability to manage } \\
\text { household chores }\end{array}$ & $\begin{array}{l}\text { Spatial disorientation; } \\
\text { perseverative utterances }\end{array}$ & $\begin{array}{l}\text { EEG: normal; spongiform } \\
\text { change most severe in the } \\
\text { frontal and temporal cortex }\end{array}$ \\
\hline III-3 & M & 42 & 04 & $\begin{array}{l}\text { Disinhibition; } \\
\text { alcoholism }\end{array}$ & $\begin{array}{l}\text { Aggressive behavior; } \\
\text { nyperorality; stereotyped behavio }\end{array}$ & ior \\
\hline III-4 & $\mathrm{F}$ & 40 & 04 & $\begin{array}{l}\text { Apathy; inability to } \\
\text { manage household chores }\end{array}$ & $\begin{array}{l}\text { Pacing; hyperorality; } \\
\text { aggressive behavior; memory } \\
\text { impairment; parkinsonism }\end{array}$ & - \\
\hline III-6 & M & 46 & 02 & $\begin{array}{l}\text { Delusions; inability to } \\
\text { drive his truck; spatial } \\
\text { disorientation }\end{array}$ & $\begin{array}{l}\text { Aggressive behavior; } \\
\text { hyperorality; memory } \\
\text { impairment; parkinsonism }\end{array}$ & $\begin{array}{l}\text { EEG: normal; Brain biopsy: } \\
\text { spongiform change in } \\
\text { the frontal cortex }\end{array}$ \\
\hline III-8 & $\mathrm{F}$ & 43 & 07 & $\begin{array}{l}\text { Inability to manage } \\
\text { household chores; disinhibition; } \\
\text { memory impairment }\end{array}$ & $\begin{array}{l}\text { Hyperorality; stereotyped } \\
\text { behavior; parkinsonism }\end{array}$ & - \\
\hline III-19 & M & 49 & 05 & $\begin{array}{l}\text { Depression; apathy; } \\
\text { obsessive behavior }\end{array}$ & $\begin{array}{l}\text { Memory impairment; spatial } \\
\text { disorientation; hallucinations; } \\
\text { parkinsonism }\end{array}$ & $\begin{array}{l}\text { EEG: normal; CT: } \\
\text { cortical and } \\
\text { subcortical atrophy }\end{array}$ \\
\hline III-21 & M & 49 & 04 & $\begin{array}{l}\text { Apathy; fearfulness; } \\
\text { memory impairment }\end{array}$ & $\begin{array}{l}\text { Hyperorality; aggressive } \\
\text { behavior }\end{array}$ & $\begin{array}{l}\text { EEG: diffuse slowing; } \\
\qquad \text { CT:normal }\end{array}$ \\
\hline III-24 & M & 44 & 03 & $\begin{array}{c}\text { Apathy; memory } \\
\text { impairment; parkinsonism }\end{array}$ & $\begin{array}{l}\text { Stereotyped behavior; } \\
\text { mutism }\end{array}$ & EEG: normal \\
\hline III-25 & M & 47 & 09 & $\begin{array}{l}\text { Apathy; inability to } \\
\text { teach technical design; } \\
\text { memory impairment }\end{array}$ & $\begin{array}{l}\text { Spatial disorientation; } \\
\text { parkinsonism; mutism; } \\
\text { myoclonus }\end{array}$ & $\begin{array}{l}\text { EEG: normal; CT: cortical and } \\
\text { subcortical atrophy } \\
\text { pongiform change most severe } \\
\text { in the frontal and temporal } \\
\text { cortex and the striatum. }\end{array}$ \\
\hline IV-13 & M & 37 & 02 & $\begin{array}{l}\text { Apathy; inability to } \\
\text { work as bank manager; } \\
\text { memory impairment }\end{array}$ & $\begin{array}{l}\text { Pacing; hyperorality; } \\
\text { aggressive behavior }\end{array}$ & - \\
\hline IV-15 & $\mathrm{F}$ & 45 & NA & Depression; apathy & $\begin{array}{l}\text { Stereotyped behavior; } \\
\text { parkinsonism }\end{array}$ & $\begin{array}{l}\text { EEG: normal; CT: cortical } \\
\text { and subcortical atrophy }\end{array}$ \\
\hline IV-62 & M & 40 & NA & $\begin{array}{l}\text { Depression; apathy; } \\
\text { parkinsonism }\end{array}$ & $\begin{array}{r}\mathrm{E} \\
\text { and } \mathrm{s} \\
\text { sig } \\
\text { ar }\end{array}$ & $\begin{array}{l}\text { EEG: normal; MRI: mild cortical } \\
\text { subcortical atrophy; DWI: high } \\
\text { ignal in striatum and in cortical } \\
\text { reas of the insulae, frontal and } \\
\text { parietal lobes; SPECT: normal }\end{array}$ \\
\hline
\end{tabular}

DWI, Diffusion-weighted magnetic resonance imaging; NA, not available.

changes became even more frequent and other signs of frontal and temporal involvement appeared. Eight patients manifested parkinsonian signs; in only three of them, these signs could have been ascribed to the side effects of neuroleptic drugs. Nine patients were first seen by a psychiatrist and eight were eventually admitted to psychiatric hospitals due to behavioral disturbances.

EEG from 8 patients failed to reveal periodic activity. Five patients were submitted to brain CT or MRI, which showed only mild cortical atrophy. SPECT was normal in the single patient where it was performed (IV-62).

\section{DISCUSSION}

The clinical features of the prion disease associated with T183A mutation are characterized by the onset of behavioral or personality disturbances, associated with a parkinsonian syndrome, in the fifth decade of life, with a mean evolution of four years. Neuropathological examinations of two cases (II-6, III-25) disclosed the frontotemporal predominance 
of the spongiform change, besides confirming the presence of the abnormal prion protein by immunohistochemistry, as described in a previous report. ${ }^{5}$

Although the genotypic and phenotypic heterogeneity in FTDP-17 is considerable ${ }^{3,4}$, the predominant features include onset in the fifth decade with a behavioral disorder characteristic of the frontotemporal dementias, accompanied by a parkinsonian syndrome. These features are similar to those of T183A patients. The mean duration of the symptoms is usually longer in FTDP-17, but as it varies widely, it may be equal to that observed in individual cases with T183A mutation. EEG is usually normal in FTDP17 , as it was in most of the cases in the present study. Neuroimaging in FTDP-17 usually shows frontotemporal atrophy and anterior hypoperfusion on SPECT. ${ }^{4}$ In contrast, brain CT did not reveal focal abnormalities in the T183A patients. Although there is a frontotemporal predominance of the disturbances, histopathological features are completely different in both conditions, as well as the genetic abnormalities.

In spite of the considerable resemblance of both diseases, a few patients with the prion disease associated with T183A presented memory impairment and even spatial disorientation as initial symptoms, which is definitively uncommon for the frontotemporal dementias.

Behavioral manifestation at the onset of the illness may also occur in other inherited prion diseases ${ }^{6-9}$. In CJD associated with other point mutations, the clinical features usually are extremely similar to the sporadic form of CJD, where, on average, symptoms begin at the age of 60 and death after 8 months of disease ${ }^{1,2,6}$. One exception is CJD associated with point mutation at codon 178 , where there is an earlier age at onset and a more protracted course. However, in this mutation, memory impairment is predominant as the initial symptom, and the clinical progression is similar to the sporadic forms of CJD, with a high frequency of cerebellar, myoclonus, extrapyramidal and pyramidal signs ${ }^{6}$.

In some families with GSSD, the cerebellar syndrome may occur later in the evolution, and prominent psychiatric or behavioral presentations have been described. In GSSD associated with point mutation at codon 117, also known as the telencephalic variant of GSSD, there is a presenile onset of behavioral or cognitive disturbances, sometimes associated with parkinsonian signs ${ }^{2,7}$.
Prominent psychiatric features have also been reported in a family with a probable mutation at codon $171^{8}$.

Insertion of octapeptide repeats in addition to the five repeats present in normal prion protein gene may be associated with prion disease exhibiting either CJD or GSSD phenotype, with earlier onset and longer duration than those associated with point mutations $\mathrm{s}^{9,10}$. Mood changes and abnormal behavior were reported in a family with 168 base pair insertion (seven extra-repeats) ${ }^{9}$ and in GSSD associated with 192 base pair insertion (eight extra repeats). In the latter, prominent psychiatric features have been reported at the onset of the illness ${ }^{10}$. As the duration is unusually long for the prion diseases, there must be a considerable chance of being mistaken for the more common frontotemporal dementia.

In conclusion, knowledge of the clinical features of the prion disease associated with T183A mutation increases the possibility of differential diagnosis both of prion diseases and frontotemporal dementias, and reinforces the concept that in the familial forms of frontotemporal dementia, similar clinical phenotypes may be related to mutations in different genes. Other inherited prion diseases may also present with behavioral or personality disturbances, which points to the importance of searching for prion diseases in the differential diagnosis of the frontotemporal dementias.

\section{REFERENCES}

1. Richardson EP Jr, Masters CL. The nosology of Creutzfeldt-Jakob disease and conditions related to the accumulation of PrPCJD in the nervous system. Brain Pathol 1995;5:33-41.

2. Collinge J, Palmer MS. Human prion diseases. In Collinge J, Palmer MS (eds). Prion diseases. Oxford: Oxford Univ Press, 1997:18-56.

3. Poorkaj P, Bird TD, Wijsman E, et al. Tau is a candidate gene for chromosome 17 frontotemporal dementia. Ann Neurol 1998;43:815-825.

4. Foster NL, Wilhelmsen K, Sima AAF, et al. Frontotemporal dementia and parkinsonism linked to chromosome 17: a consensus conference. Ann Neurol 1997;41:706-715.

5. Nitrini R, Rosemberg S, Passos-Bueno MR, et al. Familial spongiform encephalopathy associated with a novel prion protein mutation. Ann Neurol 1997;42:138-146.

6. Brown P, Goldfarb LG, Kovanen J, et al. Phenotypic characteristics of familial Creutzfeldt-Jakob disease associated with the codon $178^{\text {Asn }}$ PRNP mutation. Ann Neurol 1992;31:282-285.

7. Hsiao KK, Cass C, Schellenberg GD, et al. A prion protein variant in a family with the telencephalic form of Gerstmann-Sträussler-Scheinker syndrome. Neurology 1991;41:681-684.

8. Samaia HB, Mari JJ, Vallada HP, Moura RP, Simpson AJ, Brentani R. A prion-like psychiatric disorder. Nature 1997;390:241.

9. Goldfarb LG, Brown P, Mc Combie WR, et al. Transmissible familial Creutzfeldt-Jakob disease associated with five, seven, and eight extra octapeptide coding repeats in the PRNP gene. Proc Natl Acad Sci USA 1991;88:10296-10930.

10. Laplanche JL, El Hachimi KH, Durieux I, et al. Prominent psychiatric features and early onset in an inherited prion disease with a new insertional mutation in the prion protein gene. Brain 1999;122:2375-2386. 